\title{
Feed supplementation of grazing Merino ewes during mid-pregnancy: effect on changes in body composition and on the conceptus*
}

\author{
Pilar Frutos, O. Buratovich, F.J. Giráldez and A.R. Mantecón
}

Estación Agricola Experimental, Spanish Council for Scientific Research (CSIC)

Apdo 788, 24080-León, Spain

(Received 2 November 1998; accepted 5 July 1999)

\begin{abstract}
Twenty pregnant Merino ewes grazed a ryegrass pasture and were offered either no supplement or $500 \mathrm{~g} / \mathrm{head} /$ day of a concentrate supplement from days 30 to 90 of pregnancy. After that date, all cwes were supplemented. Maternal carcass and ,non-carcass" components, uterine walls, foetus and placentas plus cotyledons were chemically analysed. $\Lambda$ t day 90 , there was no significant difference between supplemented and non-supplemented animals in the mobilization of body reserves. However, from day 91 to 140 , a significant effect of the previous nutritional regime was observed. Body condition score on day 30 accounted for most of the fat mobilization from days 30 to 90 . Nevertheless, these mobilizations were not reflected in any significant difference in the birthweight and chemical composition of the foetus. Merino grazing sheep hence are able to compensate for feed restriction during mid-pregnancy, through the mobilization of body reserves, avoiding any influence on the foetus.
\end{abstract}

KEY WORDS: body condition score, ewes, maternal mobilization, mid-pregnancy, supplementary fecding

\section{INTRODUCTION}

Southern Europe grazing conditions are characterised by important seasonal fluctuations in the quality and quantity of grass, with pasture production being

\footnotetext{
- Supported by the EU Commission, Project AIR CT 92-0646 and the Junta de Castilla y León, Project CSI $3 / 96$
} 
high in spring and greatly reduced in autumn/winter (Alonso, 1994). This means that ewes may be exposed to undernutrition as pregnancy proceeds, as this normally occurs in winter time.

It is broadly accepted that sheep undernutrition over gestation may affect foetal growth and development, despite the ability of the mothers to buffer deleterious influences on foetal growth (Robinson, 1977, 1986, 1990; López and Robinson, 1994). Little is known, however, about the effect of nutrition during mid-pregnancy.

Maternal undernutrition during the first trimester of pregnancy has been demonstrated variously to either restrict or increase placenta, although a clear relationship between placental weight and foetal growth has not been well established (McCrabb et al., 1991, 1992; López and Robinson, 1994). The response is influenced by factors such as the severity and timing of undernutrition and the level of body reserves at the beginning of the pregnancy (McCrabb et al., 1992). Thus, a method for estimating the body reserves in a simple way would prove very useful in practical conditions (Gunn, 1983).

In general, farmers are recommended to feed submaintenance rations to pregnant ewes in mid-pregnancy provided above maintenance rations are available in the last trimester (MLC, 1981; Theriez et al., 1987), which will satisfy uterine and foctal growth requirements. This practice, however, makes the system dependent on the capacity of the ewes to compensate for the response that occurs during feeding restriction, in a subsequent period of improved nutrition.

This experiment was conducted with the aim to study the effect of supplementation over mid-pregnancy (from day 30 to 90 of gestation), of grazing Merino ewes in Southern Europe, with a range of medium-low body condition scores, on maternal composition changes and the effect on the conceptus.

\section{MATERIAL AND METHODS}

\section{Experimental design}

This work was carried out using twenty single-bcaring Merino cwes, ranging in age from 3 to 4 years old, in liveweight (LW) from 45.6 to $57.6 \mathrm{~kg}$ and in body condition score (BCS) from 1.25 to 3 , at the beginning of the experiment. The animals belonged to the flock of the research farm of the Spanish Council for Scientific Research (Conscjo Supcrior de Investigaciones Científicas, CSIC), León.

Oestrous cycles were synchronised in September using intravaginal sponges containing $60 \mathrm{mg}$ of medroxi-progesterone acetate (SINCRO-GEST ${ }^{\mathrm{B}}$ ), and all ewes were mated the same day (day 0 ). One month after mating (day 30 ), pregnancy 
was confirmed by ultrasonic scanning. Ewes received different treatments (grazing or grazing + supplementation) from day 30 to day 90 of pregnancy and then were all supplemented until day 140 . Thus, animals were allocated to 4 groups of 5 animals, according to the experimental design, as follows:

groups of animals slaughtered on day 90 :

group $\mathrm{G}-$ grazing from days 30 to 90 ,

group $\mathrm{S}-$ grazing + concentrate supplement from days 30 to 90 ; groups of animals slaughtered on day 140 :

group GS - grazing from days 30 to 90 and grazing + concentrate supplement from days 91 to 140 ,

group SS - grazing + concentrate supplement from days 30 to 140 .

A perennial ryegrass dominant pasture containing Lolium perenne, Festuca pratensis and Trifolium repens, of approximately 1 ha, was subdivided into two plots: A and B. Groups G, and GS grazed on plot A and groups S, and SS on plot $\mathrm{B}$, from day 30 to 90 . After that date, all ewes were put together in one plot and supplemented. Chemical composition of pasture during 30 to 90 -day period ranged from 892 to $843 \mathrm{~g} \mathrm{OM}, 226$ to $201 \mathrm{~g} \mathrm{CP}$ and 364 to $452 \mathrm{~g} \mathrm{NDF} / \mathrm{kg} \mathrm{DM}$. During that period, sward height averaged $2.55 \mathrm{~cm}$ in pasture A (ewes without supplementation) and $4.40 \mathrm{~cm}$ in pasture $B$ (ewes receiving supplementation; RSD $=0.970$ ).

Supplemented animals were offered as a group $500 \mathrm{~g} / \mathrm{head}$, once daily, of a concentrate supplement formulated with barley grain ( $85 \%$ ), soyabean meal (12\%) and a mineral-vitamin mixture (3\%), its composition being, \%: dry matter (DM) 93.4 and crude protein $(\mathrm{CP}) 13.4$.

\section{Slaughter}

Ewes slaughter. After a fast of $24 \mathrm{~h}$, the ewes were shorn and then slaughtered by exsanguination from the jugular vein, after being injected intravenously with 1 $\mathrm{ml}$ of Xilocine (Rompum ${ }^{3}$ ). Blood and wool collected were not analysed but were assumed to have the chemical composition described by the ARC (1980). The procedure at slaughter followed the schedule described by Frutos et al. (1997). It was designed to partition cach body into two components, carcass and ,non-carcass". The gastrointestinal tract was emptied and its contents weighed in order to obtain the empty body weight (EBW).

Uterine dissection. The uterus was tied off as close as possible to the cervix with cotton thread. After weighing the gravid uterus, an incision was made along the greater curvature of the pregnant horn and the foetus exposed. The umbilical cord was tied off with cotton thread and severed. The foetus was immediately removed and killed with a lethal dose of Xilocine (Rompum ${ }^{*}$ ), and weighed. 
Maternal carcass and „non-carcass" components, uterine walls, foctus and placentas plus cotyledons were stored in separate polyethylene bags at $-20^{\circ} \mathrm{C}$ until preparation for analysis. After thawing, they were cut into pieces and minced successively, using a blender fitted with end plates containing holes of $7 \mathrm{~mm}$ and $4 \mathrm{~mm}$ diameter. The mince was then mixed thoroughly and subsamples freeze dried.

Four further non-pregnant, non-lactating grazing Merino ewes, from the same flock, were used as initial group. These animals had been slaughtered previously for another experiment of body composition (Frutos, unpublished data) following exactly the same slaughter schedule followed in this work.

\section{Measurements and analyses}

Liveweight and body condition score (Russel et al., 1969) were recorded once per week throughout the experiment.

Herbage intake. Herbage intake by grazing ewes was estimated according to the equation developed by Linchan et al. (1947), by hand cutting of quadrats of herbage and undisturbed herbage accumulation.

Chemical analyses. All samples from slaughter, after having been freeze dricd to determine water content, were analysed for crude protein and ash by AOAC (1984) procedure. Fat content was estimated by difference.

Herbage samples from quadrats were dried in an oven at $60^{\circ} \mathrm{C}$ and then analysed for crude protein and ash (AOAC, 1984) and for NDF (Goering and Van Soest, 1970).

\section{Statistical analysis}

The experiment was analysed using analysis of variance with a factorial treatment structure. Regression analysis was used to evaluate relationships between $\mathrm{BCS}, \mathrm{LW}$ and changes in body composition. All data were analysed using Complete Statistical System (CSS, 1991).

For data relating to groups G, S, GS, and SS, analysis of variance was used to study the effect of the level of supplementation during the first half of gestation (from days 30 to 90 of the experiment) on parameters measured on days 90 (groups G and S) and 140 (groups GS and SS) of pregnancy. In order to remove the effect of liveweight at the beginning of the experiment as source of variability, this parameter was included into the analyses of variance as a covariate. Likewise, for data on day 140 concerning conceptus composition, the sex of the foetus was included in the analysis of variance as a covariate. 


\section{RESULTS}

Intake of grass from day 30 to 90 of the experiment did not show differences between supplemented and non-supplemented animals, averaging 0.62 and $0.59 \mathrm{~kg} \mathrm{DM} / \mathrm{ewe} /$ day, respectively $(\mathrm{RSD}=0.159)$

Liveweight and body condition scores of the sheep recorded on days 30,90 and 140 are presented in Table 1. There was no effect of supplementation from days 30 to 90 on any of these parameters, neither in animals slaughtered on day 90 nor on those slaughtered on day 140 of gestation.

TABLE 1 Liveweight (LW) and body condition score (BCS) recorded on days 30,90 and 140 of the experiment

\begin{tabular}{lcccccccc}
\hline Experimental group & $\mathrm{G}$ & $\mathrm{S}$ & $\mathrm{RSD}$ & $\mathrm{S}_{1}$ & $\mathrm{GS}$ & $\mathrm{SS}$ & $\mathrm{RSD}$ & $\mathrm{S}_{2}$ \\
\hline $\mathrm{LW}_{3(0)}$ & 45.97 & 50.80 & 2.736 & $\mathrm{~ns}$ & 49.83 & 51.90 & 4.929 & $\mathrm{~ns}$ \\
$\mathrm{LW}_{9(0)}$ & 48.60 & 55.30 & 2.866 & $\mathrm{~ns}$ & 52.25 & 54.95 & 6.214 & $\mathrm{~ns}$ \\
$\mathrm{LW}_{140}$ & & & & & 57.38 & 58.35 & 6.863 & $\mathrm{~ns}$ \\
$\mathrm{BCS}_{30}$ & 2.17 & 2.81 & 0.541 & $\mathrm{~ns}$ & 2.75 & 2.44 & 0.486 & $\mathrm{~ns}$ \\
$\mathrm{BCS}_{90}$ & 2.00 & 2.94 & 0.366 & $\mathrm{~ns}$ & 2.50 & 2.44 & 0.442 & $\mathrm{~ns}$ \\
BCS $_{140}$ & & & & & 2.44 & 2.44 & 0.515 & $\mathrm{~ns}$ \\
\hline
\end{tabular}

$\mathrm{S}_{1}=$ effect of supplementation from days 30 to 90 on parameters measured on animals slaughtered on day 90

$\mathrm{S}_{2}=$ effect of supplementation from days 30 to 90 on paramelers measured on animals slaughtered on day 140

Empty body composition and changes in carcass and „non-carcass" chemical composition of the ewes, from days 30 to 90 and from days 91 to 140, are given in Table 2. As shown in the table, cmpty chemical composition of the ewes slaughtered on days 90 and 140, did not show any significant difference $(P>0.05)$ due to the effect of feed supplementation from days 30 to 90 . Empty body weight represented proportionally, on average, $0.81(\mathrm{RSD}=0.038)$ of the LW.

Changes in carcass and ,non-carcass" chemical composition during the first half of the gestation were not affected by the level of supplementation during that period, either. However, changes from day 91 to day 140 , measured in ewes slaughtered on day 140, were influenced by that previous nutritional regimen. Animals from group SS showed a higher mobilization of dry matter of the carcass, accounted for, mainly, by a high loss of fat $(\mathrm{P}<0.05)$. Concerning ,non-carcass" components, protein and fat presented opposite values of mobilization in ewes that had been supplemented or not during the first half of pregnancy. All results were highly variable between individual ewes. 
TABLE 2 Empty body chemical composition and changes in carcass and ,non-carcass" chemical composition of the ewes, from days 30 to 90 (groups G and S) and from days 91 to 140 (groups GS and SS)

\begin{tabular}{lrrrrrrrr}
\hline Experimental group & $\mathrm{G}$ & $\mathrm{S}$ & $\mathrm{RSD}$ & $\mathrm{S}_{\mathrm{I}}$ & $\mathrm{GS}$ & $\mathrm{SS}$ & $\mathrm{RSD}$ & $\mathrm{S}_{2}$ \\
\hline Empty body composition & & & & & & & & \\
DM, g/kg & 466 & 527 & 29.7 & $\mathrm{~ns}$ & 490 & 489 & 38.8 & $\mathrm{~ns}$ \\
$\mathrm{CP}, \mathrm{g} / \mathrm{kg}$ & 179 & 154 & 21.7 & $\mathrm{~ns}$ & 163 & 161 & 9.2 & ns \\
ash, g/kg & 36 & 36 & 3.8 & $\mathrm{~ns}$ & 42 & 44 & 5.3 & ns \\
fat, g/kg & 251 & 337 & 51.4 & $\mathrm{~ns}$ & 285 & 284 & 48.5 & $\mathrm{~ns}$ \\
carcass, g/kg & 532 & 570 & 29.9 & ns & 518 & 522 & 7.8 & ns
\end{tabular}

Changcs in composition Carcass

\begin{tabular}{lrrrrrrrr} 
DM, g & -964 & 1758 & 1396.8 & ns & 161 & -2258 & 741.7 & $*$ \\
CP, g & 62 & 128 & 474.7 & ns & -514 & -124 & 241.5 & $*$ \\
ash, g & -383 & -143 & 190.7 & ns & 106 & 269 & 172.1 & ns \\
fal, g & -643 & 1772 & 1119.7 & ns & 569 & -2403 & 986.0 & $*$ \\
& & & & & & & & \\
Non-carcass & & & & & & & & \\
DM, g & 504 & 620 & 464.6 & ns & 340 & 306 & 1249.42 & ns \\
CP, g & 1700 & 1554 & 945.8 & ns & -373 & 434 & 282.0 & $*$ \\
ash, g & -88 & 48 & 53.0 & $*$ & 85 & 65 & 60.5 & ns \\
fat, g & -1109 & -981 & 1292.1 & ns & 629 & -192 & 1339.2 & $*$ \\
\hline
\end{tabular}

$S_{1}=$ effect of supplementation from days 30 to 90 on parameters measured on animals slaughtered on day 90

$S_{2}=$ effect of supplementation from days 30 to 90 on parameters measured on animals slaughtered on day 140

Liveweight registered on day 30 was not significantly correlated with the amount of body reserves mobilized over the period studied (days 30 to 90 of pregnancy). On the other hand, body condition score presented significant $(\mathrm{P}<0.05)$ correlation coefficients with dry matter and fat mobilization, showing cocfficients of 0.88 and 0.90 , respectively with DM and fat changes. As for LW, BCS was not correlated significantly with protein mobilization. Inclusion of both variables together (BCS and LW) did not significantly improve the accuracy of any equation.

Table 3 shows the chemical composition of the uterine walls, foetus and placenta plus cotyledons on days 90 and 140 of pregnancy.

According to the results obtained in this work, the weight of the uterine walls as well as their composition, in dry matter, protein and ash, were statistically independent on the level of supplementation during the 2 nd and 3 rd months of gestation. Protein accounted for $83 \%$ of the dry matter weight of the 
uterus. On the other hand, fat content on day 90 showed significant differences $(\mathrm{P}<0.05)$ due to supplementation over the period studied. However, this component represented a very low proportion of the dry matter. There was no evidence that this effect persisted to day 140 .

Likewise, influence of the supplementation from days 30 to 90 on the weight of the foetuses, either on day 90 or 140 , was not evident $(P>0.05)$. This was reflected in their chemical composition, which was not significantly different between treatment groups $(\mathrm{P}>0.05)$.

The same lack of significant differences, due to the supplementary feeding from day 30 to 90 , was observed in all parameters relative to the placenta+cotyledons. Only its fat content on day 140 was significantly affected $(\mathrm{P}<0.05)$ by the feeding regimen during the first phase. However, once again, any meaningful interpretation should take into account the low proportion of dry matter represented by the fat content and the high variability found between animals.

TABLE 3

Chemical composition of the uterine walls, foetus and placenta plus cotyledons, on day 90 (groups $G$ and S) and on day 140 (groups GS and SS) of pregnancy

\begin{tabular}{|c|c|c|c|c|c|c|c|c|}
\hline Experimental group & G & $S$ & RSD & $S_{1}$ & GS & SS & $\mathrm{RSD}$ & $\mathrm{S}_{2}$ \\
\hline \multicolumn{9}{|l|}{ Uterine walls } \\
\hline weight, g & 272 & 265 & 39.5 & ns & 706 & 654 & 83.4 & $\mathrm{~ns}$ \\
\hline $\mathrm{DM}, \mathrm{g} / \mathrm{kg}$ & 162 & 163 & 5.7 & ns & 170 & 210 & 29.0 & ns \\
\hline $\mathrm{CP}, \mathrm{g} / \mathrm{kg}$ & 133 & 140 & 6.1 & ns & 137 & 171 & 20.6 & ns \\
\hline ash, $\mathrm{g} / \mathrm{kg}$ & 10 & 10 & 0.2 & ns & 11 & 14 & 2.0 & ns \\
\hline lat, $\mathrm{g} / \mathrm{kg}$ & 19 & 13 & 1.9 & $*$ & 22 & 25 & 8.0 & ns \\
\hline \multicolumn{9}{|l|}{ Foctus } \\
\hline weight, g & 408 & 376 & 38.4 & ns & 4482 & 4179 & 283.3 & ns \\
\hline $\mathrm{DM}, \mathrm{g} / \mathrm{kg}$ & 150 & 153 & 5.3 & ns & 196 & 193 & 8.9 & ns \\
\hline $\mathrm{CP}, \mathrm{g} / \mathrm{kg}$ & 93 & 90 & 2.3 & $\mathrm{~ns}$ & 133 & 130 & 9.2 & ns \\
\hline ash, $\mathrm{g} / \mathrm{kg}$ & 30 & 32 & 1.4 & ns & 27 & 28 & 5.0 & $\mathrm{~ns}$ \\
\hline fat, $\mathrm{g} / \mathrm{kg}$ & 27 & 31 & 1.6 & ns & 35 & 35 & 5.9 & ns \\
\hline \multicolumn{9}{|l|}{ Placenta + cotyledons } \\
\hline weight, $g$ & 807 & 1017 & 141.9 & $\mathrm{~ns}$ & 862 & 726 & 186.8 & ns \\
\hline $\mathrm{DM}, \mathrm{g} / \mathrm{kg}$ & 103 & 93 & 9.6 & $\mathrm{~ns}$ & 142 & 136 & 6.6 & $\mathrm{~ns}$ \\
\hline $\mathrm{CP}, \mathrm{g} / \mathrm{kg}$ & 80 & 73 & 6.8 & ns & 107 & 108 & 6.7 & $\mathrm{~ns}$ \\
\hline ash, $\mathrm{g} / \mathrm{kg}$ & 10 & 11 & 0.3 & ns & 10 & 11 & 1.1 & $\mathrm{~ns}$ \\
\hline fat, $\mathrm{g} / \mathrm{kg}$ & 13 & 10 & 2.9 & ns & 25 & 18 & 2.4 & $*$ \\
\hline
\end{tabular}




\section{DISCUSSION}

According to estimates of the energy requirements for pregnant ewes by the AFRC (1990), only supplemented ewes showed a positive balance over the first period (days 30 to 90), when requirements are relatively low (Bell, 1984). Protein balance, according to AFRC (1992) was positive in all animals throughout the experiment. As expected, supplementation with $500 \mathrm{~g}$ of concentrate/animal/day did not suppress forage intake (Orr and Treacher, 1984).

Until day 90 , there was no significant $(\mathrm{P}>0.05)$ difference between supplemented and non-supplemented animals in body reserves mobilization. However, from day 91 to 140 , there was a significant effect of the previous feeding regime. The capacity of fat animals to mobilize their reserves much casier than thin animals has been noted by a number of workers (Rattray et al., 1980; McCrabb et al., 1990). Accordingly, group SS (ewes supplemented from day 30 to day 90 , and slaughtered on day 140) showed a higher ability to mobilize body reserves, over the second half of pregnancy, as a consequence of the fat accumulation in the previous period.

Different patterns of fat and protein mobilization, from carcass and ,non-carcass" components, were noted in this experiment, depending on the phase of the pregnancy. Although the low number of animals and the high variability observed between them do not permit firm conclusions, there may be a number of explanations for some unexpected results such as the loss of protein and gain of fat by group GS vs the loss of fat and gain of protein by group SS, from days 91 to 140 . These may be due to subtle differences in body composition in the previous phase interacting with subtle differences in foetal weights and thereby leading to different degrees of mobilization of fat and protein from the maternal body. In addition, there may have been an effect of the differences in the relative development of the visceral organs during pregnancy on energy/protein requirements and therefore on the nature of tissue mobilization. Furthermore, the likely unbalanced energy/protein ratio, in the whole diet (grass+supplement), over the last period of pregnancy, also may have had some influence on the tissues that were mobilized.

It has been reported that the level of body reserves at the beginning of pregnancy contributes to the effect which maternal undernutrition during mid-gestation has on placental growth and consequently on foetal growth (McCrabb et al., 1992). For that reason, relationships of LW and BCS with maternal fat and protein changes during the first half of pregnancy were examined to find estimators of maternal ability to mobilize body reserves. Contrary to the results of Wright and Russel (1984) and Frutos et al. (1997) neither BCS nor LW were significantly correlated with protein changes. Body condition score on day 30 accounted for most of the fat mobilization from days 30 to $90\left(\mathrm{r}^{2}=0.81 ; \mathrm{P}<0.05\right)$. However, no changes in BCS throughout the experiment were observed in group SS (see Table 1), despite 
the observed mobilization of fat by this group. Consequently, relationships between BCS and fat mobilization during pregnancy were studied separately for groups receiving supplementation over the first phase (S and SS) and groups without supplement ( $\mathrm{G}$ and GS). The correlation coefficient for the relationship was significant when animals were not supplemented $(\mathrm{r}=0.94 ; \mathrm{P}<0.05)$ and not significant $(\mathrm{r}=0.55 ; \mathrm{P}>0.05)$ when they were supplemented. In this regard, it should be noted that there are inherent dangers in relying on LW or indeed BCS targets during pregnancy as indices of adequate nutrition (Robinson, 1986). Furthermore, mobilizations of tissues over the second and third months of gestation were not reflected in any significant differences in the growth and development of the foctus (birth weight, chemical composition, etc.) which reduced the usefulness and importance of the BCS as estimator of mobilizations during this phase of gestation.

Maternal undernutrition during mid-pregnancy has been demonstrated variously to either restrict or increase placental weight (McCrabb et al., 1992) with the effects appearing to be mediated through the endocrine status of the dam (López and Robinson, 1994). However, no significant differences in placental weight and composition were found in the present experiment. Placental growth is sensitive to maternal feed restriction during the late stages of mid-pregnancy but only under conditions when ewes have severely depleted body reserves (McCrabb et al., 1992). Probably in this work, grazing Merino ewes did not use their body reserves to a critical point, despite having only medium-low BCS (notes ranging from 1.25 to 3.00 ), which would have protected both their body reserves and foetal tissues from potential negative consequences of undernutrition during mid-gestation. Thus, neither the birth weight nor composition of the lamb were affected by feed restriction over the second and third months of pregnancy, which has also been reported by other authors (Holts et al., 1986, 1992). Indeed Holst et al. (1992) found that in ewes which had suffered undernutrition during mid-gestation, foetal growth rates were restored after refeeding.

From a general standpoint, it seems clear that, within certain limits, feeding level in the first months of pregnancy has little affect on early foetal growth (Robinson, 1977). The introduction of supplementary feed at about 90 days of gestation has been widely recommended in practice (MLC, 1981) since a partial compensation of earlier detrimental effects on foctal growth can occur by a higher plane of nutrition in late pregnancy. These are accompanied by positive changes in maternal composition in the subsequent period of better nutrition.

The results obtained in the present study extend the general recommendations about supplementary feeding during gestation to the Southern Europe grazing systems, where pastures are characterised by large fluctuations in quality and allowance of grass during different scasons and cwes have inadequate body condition to enable them to protect their pregnancy by mobilizing body reserves during peri- 
ods of maternal undernutrition. However, in this experiment, it was demonstrated that Merino sheep at pasture were able to compensate for feed restriction, through the mobilization of body reserves, thereby avoiding any detrimental effect on foetal weight and composition.

Under practical conditions similar to those exposed in this experiment, grazing sheep production systems in Southern Europe should take the present findings into account, so that objective management decisions can be used in the development of economically viable systems.

\section{REFERENCES}

AFRC, 1990. Nutritive Requirements of Ruminant Animals: Energy. Nutr. Abstr. Rev., B 60, $729-804$

AFRC, 1992. Nutritive Requirements of Ruminant Animals: Protein. Nutr. Abstr. Rev., B 62, $787-835$

Alonso I., 1994. Ecological study and cvaluation of a grazing system in León Mountains, Northern Spain (in Spanish). PhD Thesis. University of León (Spain)

AOAC, 1984. Official Methods of Analysis of the Association of Official Agricultural Chemists. 10th Edition. Washington, DC

ARC. 1980. The Nutrient Requirements of Ruminant Livestock. Technical Review by an Agricultural Research Council working party. CAB International, Wallingford (UK)

Bell A.W., 1984. Factors controlling placental and foctal growth and their effects on future production. In: D.R. Lindsay, D.T. Pearce (Editors). Reproduction in Sheep. Cambridge University Press, London, pp. 144-152

CSS. 1991. Complete Statistical System. Statsoti. Inc. Tulsa, USA

Frutos P., Mantecón A.R., Giráldez. F.J., 1997. Relationship of body condition score and live weight with body composition in mature Churra ewes. Anim. Sci. 64, 447-452

Goering M.K., Van Soest P.J., 1970. Forage Fiber Analysis (Apparalus, Reagents, Procedures and some Applications). Agriculture Handbook, No 379. Agricultural Research Service, USDA. Washington, DC

Gunn R.G., 1983. The influence of nutrition on the reproductive performance of ewes. In: W. Haresing (Editor). Shecp Production. Easter School, Bulterworths, London, pp. 99-110

Holst P.J., Killeen I.D., Cullis B.R.. 1986. Nutrition of the pregnant ewe and its effect on gestation length, lamb birth weight and lamb survival. Aust. J. Agric. Res. 37, 647-655

Holst P.J., Allan, C.J., Gilmour A.R., 1992. Effects of a restricted diet during mid pregnancy of ewes on uterine and fetal growth and lamb birth weight. Aust. J. Agric. Res. 43, 315-324

Linehan P.A., Lowe J., Stewart R.H., 1947. The output of pasture and its measurement. Part II. J. Brit. Grassl. Soc. 2. 145-168

López S., Robinson J.J., 1994. Nutrition and pregnancy in sheep (in Spanish). Invest. Agraria: Prod. Sanidad Anim. 9, 189-219

McCrabb G.J., Egan A.R., Hosking B.J., 1990. The effect of maternal body condition on glucose metabolism and foctal growth during late pregnancy. Proc. Aust. Soc. Anim. Prod. 18, 519

McCrabb G.J., Egan A.R., Hosking B.J., 1991. Maternal undernutrition during mid-pregnancy in sheep: placental size and its relationship to calcium transfer during late pregnancy. Brit. J. Nutr. 65. 157.168 
McCrabb G.J., Hosking B.J., Egan, A.R., 1992. Changes in the maternal body and feto-placental growth following various lengths of feed restriction during mid-pregnancy in sheep. Austr. J. Agric. Res. 43, 1429-1440

M.L.C., 1981. Feeding the Ewe. Sheep Improvement Services. Meat and Livestock Commission. Bletchley, Milton Keynes

Orr R.J., Treacher T.T., 1984. The effect of concentrate level on the intake of hays by ewes in late pregnancy. Anim. Prod. 39, 89-98

Rattray P.V., Trigg, T.E., Ulrich C.F., 1980. Energy exchanges in twin-pregnant ewes. In: L.E. Mount (Editor). Energy Metabolism. Butterworths, London, pp. 325-328

Robinson J.J., 1977. The influence of maternal nutrition on ovine foctal growth. Proc. Nutr. Soc. 36, 9-16

Robinson J.J., 1986. Changes in body composition during pregnancy and lactation. Proc. Nutr. Soc. $45,71-80$

Robinson J.J., 1990. Nutrition in the reproduction of farm animals. Nutr. Res. Rev. 3, 253-276

Theriez, M., Bocquier, F. Brelurut, A., 1987. Feeding allowances for ewes for maintenance and pregnancy (in French). Bull Tech. CRZV-Theix, INRA, 70, 185-197

Wright I.A.. Russel A.I.F., 1984. Estimation in wive of the chemical composition of bodies of mature cows. Anim. Prod. 38, 33-44

\section{STRESZCZENIE}

Dożywianie owiec-maciorek, w okresie środkowej ciąży, utrzymywanych na pastwisku i jego wplyw na zmianę składu ciala i zapłodnienic

Dwadzicścia kotnych maciorek merynosa wypasano na pastwisku, z przewagą rajgrasu, przy czym część zwierząt otrzymywała dodatek paszy treściwej, $500 \mathrm{~g} / \mathrm{sztuka} / \mathrm{dzień}$ od 30 do 90 dnia ciąży. W 90-ym dniu ubito czçść maciorck z każdej grupy. Od 91 dnia ciąży wszystkie pozostałe maciorki otrzymywały dodatck paszy treściwej i zostały ubite w 140 dniu kotności.

Oznaczono skład chemiczny tuszy i składników ,nje tuszy”: macicy, płodów oraz łożyska i kotyledonu. U maciorek ubitych w 90 dniu ciąży nic stwierdzono różnic miçdzy grupami w uruchomieniu rezerw ciała. U zwierząt ubitych w 140 dniu ciąży stwierdzono istotny wpływ zastosowanego systemu zywienia na wyniki poubojowe. lecz nic odbiło się to na masie ciała przy urodzeniu i składzic chemicznym płodu.

Wyciągniçto stąd wniosck, że maciorki merynosa utrzymane na pastwisku są zdolne do kompensowania niedoboru paszy w środkowym okresie ciąży poprzez mobilizację rezerw ciała, bez ujemnego wpływu na rozwój plodu. 